OPEN ACCESS

Edited by:

Monika Urban,

University of Bremen, Germany

Reviewed by:

Benjamin W. Kelly,

Nipissing University, Canada

Karin Anna Petersen,

University of Bergen, Norway

*Correspondence:

Lucia Artner

artner@uni-hildesheim.de

Specialty section:

This article was submitted to

Sociological Theory,

a section of the journal

Frontiers in Sociology

Received: 02 December 2017 Accepted: 05 October 2018

Published: 30 October 2018

Citation:

Artner L (2018) Materialities in and of Institutional Care for Elderly People.

Front. Sociol. 3:30.

doi: $10.3389 /$ fsoc. 2018.00030

\section{Materialities in and of Institutional Care for Elderly People}

\author{
Lucia Artner* \\ Institute for Social Work and Organization Studies, University of Hildesheim, Hildesheim, Germany
}

Since some decades, nursing homes for elderly people are discussed as "total institutions" in the sense of Erving Goffman. However, this line of research has not clarified yet as to how the creation of a totalizing nursing home is actually achieved on the basis of everyday practices and interactions. In my contribution I address this research gap by looking at how material and spatial arrangements in nursing homes for elderly people affect the ways its residents are socially constructed. By drawing on Goffman's ideas on the creation and presentation of the self, I engage with the question of how the placement and handling of material objects in nursing interactions lead to the institutionalization of a resident's self: Empirical examples of how materialities are deployed demonstrate how residents are stripped of their self-identity and how nursing staff members exercise rigid control over their everyday lives. Yet, it is also shown how the usage of material objects help residents to subvert some of these practices. I argue that looking at the material and spatial arrangements of a nursing home on a micro-level of social interactions helps us especially in reconstructing those often latent, inconspicuous and overseen processes in which a totalizing environment is created.

Keywords: care and nursing for elderly people, total institution, materialities in and of nursing and care, material care studies, organization ethnography

\section{INTRODUCTION}

Why should we consider material objects ${ }^{1}$ when we examine age and aging in its various manifestations? Why should materiality matter at all? One of the central premises of Material Culture Studies is that it is important to look at the constitutive role of materiality for social experience in all its diverse and differing forms (cf. Appadurai, 1986; Miller, 1987). Yet, as some argue, not all things matter and not all the time (c.f. Hahn, 2005, 2015). Within Material Culture Studies or Science and Technology Studies there is a tendency to emphasize the changeable, polysemic and ambiguous nature of things (cf. Korff, 2005; Frers, 2010; Ludwig, 2011; Hahn, 2015). Yet, certain things do indeed matter (cf. Miller, 2005). I would assert that there are certain symbolic properties of material objects that are somehow fixed, at least to one person and at least for a certain period of time. This means that things may be used to reproduce specific ideas about a person, such as being an elderly person. As this contribution will explore in more detail, things may be of relevance to the staging of oneself (Goffman, 1961, p. 27, cf. 1959, p. 32ff.). Also, and this will be the main focus here, materiality in its interplay with spatial arrangements is crucial for the formation of certain institutions for geriatric care: By looking at nursing homes for elderly

${ }^{1}$ Within Material Culture Studies, the term "thing" is mostly used and encompasses all material items, including those objects which are not produced by human beings; things that occur "naturally", but which are used and modified by humans (Hahn, 2014: 19). Therefore, I will also mainly use the term thing in this article. 
people and their material-spatial arrangements this contribution draws heavily on the concept of the "total institution" by Erving Goffman (1961) and how this is discussed with regard to institutional elderly care. While most research into nursing homes as-however "moderate" (Koch-Straube, 2003, p. 346)total institutions do not adequately consider their material and spatial arrangements, this paper takes a closer look at the placement and role of things in institutionalized nursing interactions. In his Asylums Goffman took a special interest in how "the physical facts of an establishment can be explicitly employed to frame the conception a person takes of himself" (Goffman, 1961, p. 150)-or of herself. Goffman displayed a certain sensitivity for "the relationship between self and site" (Alworth, 2014, p. 6) with regard to certain material and spatial arrangements within a total institution which this paper addresses.

Starting point of my argument is the relationality of space, materiality, and nursing practices: space and materialities as well as the members of an institution like a nursing home (be it total or not) are never neutral actors, together, reciprocally, they construct what is known as a nursing home (cf. Natter and Jones, 1997; Löw, 2001; Hujala and Rassinen, 2011). Hence, in this paper, material and spatial environments are conceptualized as both, being products of and producers of social realities in a nursing home. Until today, only little research has been done into the concrete materialities of nursing and care for elderly people or how things shape the processes involved (cf. Artner and Atzl, 2018). ${ }^{2}$ Looking at the role of things can advance some of the central concepts or perspectives regarding materiality, especially those that point to the situational embeddedness of materiality in our everyday life and that emphasize the need for close examination of the interactions between things and people on a micro-level (cf. Hahn, 2014). This is where my research on things in elderly care is located.

In order to outline the argument of the relevance of material objects in institutional elderly care, in the second part, I will take a closer look at inpatient care for elderly people and how this is discussed in the sense of Goffman's concept of the total institution. In the third part, I will outline how the material and spatial arrangements are discussed within research on nursing homes as total institutions and why there are shortcomings when it comes to the consideration of the role that things play in these contexts. I will present and discuss some of my empirical findings ${ }^{3}$ about the effects of the spatial arrangements of things

\footnotetext{
${ }^{2}$ One important exception is the joint project funded by the Federal Ministry of Education and Research from February 2014 to January 2017: "Care and ThingsObjects and their Significance in Past and Present Nursing Practice" (grant number 01UO1317A-D; see also Artner et al., 2017). At this juncture, I would like to express my very special thanks to Isabel Atzl, Anamaria Depner, André Heitmann-Möller, and Carolin Kollewe for their many years of extremely productive collaboration.

${ }^{3}$ Within this research study, the access to the care homes for elderly people where the research was conducted was ensued through their management staff. An ethics approval was not required for this study as per institutional and national guidelines. Oral informed consent was obtained from all research participants, in accordance with institutional and national guidelines (c.f. Deutsche Forschungsgemeinschaft (DFG), 2013, 2014). All participants were informed that the data collection (interviews, participant observations) could be stopped at any point in time and that all the data gathered (especially all the names of persons,
}

in a nursing home in Germany in the forth part. In the final part, I will draw a conclusion on the specific roles which things can have in the (totally) institutionalized form of care that is a nursing home.

\section{INSTITUTIONAL ELDERLY CARE}

In the second part I want to outline, first, what form institutional elderly care can take using the example of Germany, whose organization of nursing and care for elderly can be compared to those of other OECD-countries (cf. Pavolini and Ranci, 2008). Secondly, I will demonstrate how this is primarily discussed with regard to Goffman's idea of a total institution. Ending this section, I will elaborate on the shortcomings of one of Goffman's most famous concepts and his perspective on the role of material and spatial arrangements in a total institution.

\section{Institutional Elderly Care in Germany}

Since the early 1990s the number of care recipients living in nursing homes in Germany has increased by more than $50 \%$, even though the majority of people in need of care live and are nursed in their own homes (Heinzelmann, 2004, p. 31). Nevertheless, in nursing homes for the elderly, over $60 \%$ of the residents suffer from dementia, albeit in varying forms and degrees (Schneekloth and Wahl, 2007, p. 9).

In Germany, nursing homes for elderly people are the more traditional institutionalized way of living and of caring for elderly people, most of whom are over the age of 80 . One central characteristic of nursing homes is the full coverage of services including care, nursing and day-to-day needs: Alongside care and nursing, this includes preparing meals and helping people to eat, cleaning rooms, medical treatment, educational and entertainment programs, sports activities and so on (Posenau, 2014, p. 19). Besides watching television and listening to the radio or interacting with other residents, at least half of the residents in nursing homes participate in the collective activities offered by the institution (Schneekloth and Wahl, 2007, p. 10). Most nursing homes also offer pastoral care and terminal spiritual care (Schneekloth and Wahl, 2007).

Many activities in nursing homes are explicitly determined by the German social security legislation. Since 1995 and the inception of the German long-term care insurance act, nursing and care services provided by nursing homes have been restricted to four central areas (Hämel, 2010, p. 187f). People in need of care and nursing must be supported in the areas of:

1) personal hygiene (e.g., bathing, dental care, support in excretion),

2) nourishment (e.g., bite-sized food preparation, support with food intake),

3) mobility (e.g., getting up and going to bed, dressing and undressing, walking, standing and so forth), and

4) household activities (e.g., shopping for groceries, cleaning, washing dishes and clothes).

institutions, cites and so forth) is anonymized. I would like to thank all participants for their support. 
Compared to home health care, we find that inpatient care (apart from semi-residential care and short-term care) is conceptualized as 24-h full-service care, thus holistically affecting its residents: after moving into a nursing home, a resident's options are more or less reduced to the act of purchasing additional services provided by the respective establishment, such as paying a visit to the in-house hairdresser (Schmidt, 1999, p. 51ff.). Residents and/or their relatives are not expected to participate in the arrangement and organization of a facility (its living areas, its social services and so forth; Hämel, 2010, p. 187f.). The specific nature of these services is decided by the management or the provider of each establishment; some nursing homes have an advisory board of residents that have a say in this (Posenau, 2014, p. 19). These matters also depend on the size of a nursing home, which varies from facility to facility (from 10 to more than 100 people), and the way they are managed, from private individuals to communities, from churches and charitable organizations to companies (Heinzelmann, 2004, p. 32). In fully residential establishments, caring, nursing and maintenance are provided by professionally employed people (albeit often in precarious employment situations), usually in specific routine procedures. The required duties of nursing and care are delivered by these members of staff, who must also document their activities on a daily basis.

In sum, nursing homes (in Germany) are said to be instrumentally rational (Dathe, 2014, p. 170; cf. Strauch, 1978 , p. 104) and in order to meet their objective they are systematically organized, which i.a. entails a differentiation of their members along different roles (nurses, residents and other care staff). This implies that institutions control the construction of their clients' self which results in specific normative ideas about e.g., what it means to be old and living in a nursing home for elderly people. The image of the elderly in nursing homes can range from helplessness, neediness, being of an undemanding nature or in need of activation to being able to be activated, having a right to one's individuality and self-determination (Dathe, 2014, p. 174ff.). However, structural constraints, such as chronic understaffing often force nursing and care staff to gravitate toward the first image of needy elderly people (Dathe, 2014). It has been shown that this may also cause some forms of "learned helplessness and instrumental passivity" (Harper Ice, 2002, p. 346). But there are even more constraints that residents in nursing homes for elderly people might face. The next part will discuss this with a special focus on Goffman's idea of a total institution.

\section{Nursing Homes for Elderly People as "Total Institutions"}

One characteristic of many societies worldwide is a distinction between places where we live, where we sleep, clean ourselves, where we spend our leisure time and/or where we work. In a so-called "total institution" as defined by the sociologist Erving Goffman (1961), this separation is suspended for its inhabitants or members. All activities in everyday life happen at the same place: the institution. By this, Goffman meant jails, psychiatric wards, hospitals and also nursing homes. ${ }^{4}$ Members of these institutions generally share the same fate as "like-situated individuals, cut off from the wider society for an appreciable period of time" who "together lead an enclosed, formally administered round of life" (Goffman, 1961: xi). Their daily conduct is largely prearranged and determined by the staff working in them: Everyday life is scheduled by the institution, all members are treated in the same way, they all have to follow the same institutional rules. One central characteristic is the unequal distribution of power between the members and the staff. ${ }^{5}$ This inequality is critical for the social construction of the self; how the members of a total institution see themselves and are perceived by others. Besides being segregated from wider society, inmates in a total institution share the same fate of living in the company of a group of similar others (Goffman, 1961, p. 17) which receive the same treatment and daily activities that are for the most part prearranged on a schedule by the institution. Additionally, inmates are subject to certain procedures that lead to an undeniable kind of stripping of self identity which inter alia includes the loss of one's possessions but also the intrusion of one's privacy.

Since the late 1960s, the concept of the total institution has also been discussed with regard to nursing homes for elderly people (for the US see Hook et al., 1982; Kahn, 1999; Harper Ice, 2002; Kaup, 2011; for the UK see King and Raynes, 1968; King et al., 1973; Jenkins et al., 1977; Clark and Bowling, 1990; for Germany see Koch-Straube, 2003; Heinzelmann, 2004; Amrhein, 2005; Roth, 2007; Pöschel, 2013). The critiques which were formulated have caused some changes in the organizational structures of nursing homes, inter alia regarding the residents' rights (Heinzelmann, 2004, p. 57). These changes have, however, led to the idea that the term "total institution" might be an exaggeration, as nursing homes are certainly not prisons or psychiatric wards (Prahl and Schroeter, 1996, p. 173, cf. Richard, 1986; Gebert and Kneubühler, 2001). Even though nursing homes for elderly people were identified as total institutions by Goffman himself-as those types of "institutions established to care for persons felt to be both incapable and harmless" (1961: 15)-the debates surrounding nursing homes increasingly moved away from a stricter definition: "Most research on elderly people in institutional care has implicitly collected data which is pertinent to Goffman's model. These studies, through data on patient satisfaction, level of daily activity, amount of privacy and flexibility of routines appear to confirm that the features of total institutions are difficult to overcome, except in very small hostels

\footnotetext{
${ }^{4}$ Goffman differentiates five distinct categories of total institutions. Nursing homes belong to the first category, establishments where the main function is to "care for persons felt to be both incapable and harmless; these are the homes for the blind, the aged, the orphaned, and the indigent" (Goffman, 1961: 16).

${ }^{5}$ As Goffman indicates (see for example 1961: 15), the experiences of people within total institutions vary from establishment to establishment. A prison and a psychic ward might put more restrictions on its inmates as hospitals or nursing homes Additionally, the degradation of the self also depends on an individual's socioeconomic resources. Therefore, the distribution of power within a nursing home might also vary between, for example, luxurious facilities that offer high-end care services compared to those with more basic care supply.
} 
and homes" (Townsend, 1962; King and Raynes, 1968; cf. King et al., 1973; Jenkins et al., 1977; Davies and Snaith, 1980; Godlove et al., 1981; Clark and Bowling, 1990, p. 1202, Foldes, 1990; Thomas, 1994; Kahn, 1999). This is why some have suggested conceptualizing nursing homes more as a sort of "moderate total institution" (Koch-Straube, 2003, p. 346; translation by the author).

Due to the mentioned changes we currently find a wide range of different forms of nursing homes for elderly people with quite different concepts of caring and nursing as well as of age and aging. However, within the German context, most nursing homes are still very functional: the aspects of living and dwelling in these institutions are for the most part oriented toward a cost-effective organization of nursing and care (Prahl and Schroeter, 1996, p. 154f.).

According to the seminal ethnographic study by Ursula Koch-Straube (2003), nursing homes still present some striking characteristics of a total institution. This applies, for example, to the constraints of social interactions for the residents of nursing homes or the rigorous planning of their everyday life, as well as the fact that all affairs of daily life happen at the same place in the nursing home. For these reasons, the residents of nursing homes have practically no privacy, as this is almost entirely under the control of the staff. An institutional environment might have a negative impact on a residents' quality of life, leading to a higher rate of psychological distress symptoms amongst older people (cf. Voyer et al., 2005). This is one reason why some studies emphasize the role that the spatial arrangement has in this regard: "The idea here is primarily to develop a momentary and positive 'sense of place' for older people." (Andrews et al., 2005, p. 114) Hence, the focus is put on "unique place-experiences and what they mean to older people with different physical and cognitive abilities" (Andrews et al., 2005). These places should also resemble what was coined as "therapeutic landscapes" i.a. by health geographers (Andrews et al., 2005, cf. Gesler, 1992): "Therapeutic landscapes refer to the positive psychological associations that people attach to places, and concurrently their perceived restorative and healing qualities of places" (Andrews et al., 2005: 115).

The research on nursing homes as total institutions has not clarified in detail how staff exercise rigid control and display patronizing behavior, and how exactly an impersonal atmosphere is actually achieved in daily practice. There is still a lack of research on the micro-level that deals with the actions and interactions in a nursing home as a total institution on the ground. This is where my concern with material and spatial arrangements in a nursing home comes in: as I want to demonstrate in this paper, things and the way they are spatially arranged can have a considerable impact on the way elderly people are constructed as residents of a nursing home. Doing so, I will also pick up on the critique toward Goffman's concept of the total institution and especially his approach toward materiality as will be outlined in the next section.

\section{Critique Toward Goffman's Approach to Materiality}

Some critiques of Goffman's concept of the total institution emphasize the undermining of the role that material and spatial arrangements actually have in achieving a total institution in day to day social interactions-even though they "were 'total' insofar as they physically confined their inmates, limiting their access to valued resources: not only material possessions but also time, personal space and control over one's daily routine" (Scott, 2010, p. 214) ${ }^{6}$

It is said that Goffman does not take material objects into consideration as a factor in their own right, that might shape social interactions: "Goffman $(1959,1961)$, also pays attention to the material arrangements of people and objects within the 'interaction situation.' Notions like 'co-presence,' 'face work,' and 'front and back stage' draw attention to the material arrangements among human beings that enable and constrain social interaction, but Goffman treats materiality per se as something like a stage on which all the interesting performances occur." (Pinch, 2008, p. 463) This judgment might be confusing as other critics especially emphasize that "Asylums and other books are remarkably attentive to the nonhuman" (Alworth, 2014, p. 4). Goffman himself writes in Asylum that he seeks to reconstruct the "encompassing or total character" of total institutions and how it "is often built right into the physical plant" taking the shape of "locked doors, high walls, barbed wire, cliffs, water, forests, or moors" (Goffman, 1961, p. 16). Yet, throughout the book he treats material objects as if they merely provided the setting of an interaction but to a lesser extent as something which is part of them (Pinch, 2008, p. 463).

As will be demonstrated in the following sections, a very important distinction must be made when it comes to certain kinds of material aspects, namely those that are used to foster a sense of oneself: Goffman took a special interest in how "the physical facts of an establishment can be explicitly employed to frame the conception a person takes of himself" (Goffman, 1961, p. 150)-or of herself. Goffman displays a certain sensitivity for "the relationship between self and site" (Alworth, 2014, p. 6). I will seize on these ideas regarding the effects of the material and spatial arrangements of a nursing home for elderly people in more detail in the following.

\section{MATERIAL AND SPATIAL ARRANGEMENTS OF TOTALIZED INSTITUTIONAL ELDERLY CARE}

Before I discuss how certain materialities or things influence the construction of oneself within a nursing home seen as a total institution in the sense of Goffman with regard to my own research, in this section I will outline what I mean when I refer

\footnotetext{
${ }^{6}$ There were of course more points of critique towards Goffman's concept which for reason of limited space can only be shortly mentioned here. Scott (2010: 217) brings in three critical discussions: 1. overemphasizing the coercive identity erasure taking place on total institutions and overlooking the subtle processes of negotiation, legitimation and mutual surveillance through which power operates in the interaction order; 2 . methodological flaws and questions of representativeness: "institutions vary in their degrees of totality, just as inmates vary in their degree of commitment to them" (Scott, 2010: 217); 3. the nature of total institutions has changed since Goffman conducted his research in the 1960's, especially those establishments linked to (mental) health care, even though some totalizing momentum still exists there (cf. Quirk et al., 2006; Goodman, 2013).
} 
to space (Space in and of a Nursing Home for the Elderlies) and things (Things in Institutionalized Elderly Care).

\section{Space in and of a Nursing Home for the Elderlies}

Space and materialities as well as the members of an institution like a nursing home (be it total or not) are never neutral actors, together, reciprocally, they construct what is known as a nursing home (cf. Natter and Jones, 1997; Löw, 2001; Hujala and Rassinen, 2011). The production of space that Martina Löw (2001: 53), as well as others, describes is a highly complex undertaking which (to save time) will be described here in a simplified way: space is a relational social category, produced by an interplay between people and material objects. Or, as Wolfgang Natter and Jean Paul Jones describe it, "space is produced by social relations that it also reproduces, mediates and transforms. [...] Therefore, in contrast to a category of space as self-present social essence, it is more useful to start with a conception of space that, like the subject, is a lack to be filled, contested, and reconfigured through contingent and partially determined social relations, practices, and meanings." (Natter and Jones, 1997, p. 149, italics in original) Furthermore, we have to assume that there is a reciprocity between space and social order: "While we construct our work environment or merely act in it, the environment, for its part, constructs, creates, maintains or changes us-our identity, our status and position in the social order, even our bodies." (Hujala and Rassinen, 2011, p. 441).

Health and nursing research increasingly take the role of place in nursing homes into consideration, yet, "the growing social and health geography literature focused on caring that, to date, has lacked an emphasis on the mechanisms of caring practices and, in particular, on the caring practices of health professionals" (Andrews et al., 2005, p. 111). The question of how a nursing home is accomplished, how it is (spatially) designed and how nursing practices take shape through the actual placement of people and things has not yet been sufficiently taken into consideration. Nevertheless, the spatial arrangements of nursing homes did gain some attention recently within gerontology (cf. Meyer et al., 2017) or nursing studies (cf. Hujala and Rassinen, 2011).

The architectural structure of a nursing home usually allots residents fixed places for sleeping, eating and for carrying out other activities, such as gymnastics. This in turn usually makes it easier for the staff to efficiently do their jobs and to control the organizational procedures. In nursing homes, we find public areas, such as the external façade and its local environment. We find semi-public areas, such as the entrance, the cafeteria or certain corridors. There are semi-private areas, such as the residential units or groups, and their shared spaces, such as a dining room and/or living room. Last but not least, there are private areas, such as the residents' private rooms. ${ }^{7}$ These private rooms function as places to live and sleep, sometimes also to cook and eat. This is also the place where residents are nursed and cared for, where their personal hygiene is taken care of. Unlike

${ }^{7}$ For a more detailed description of the spatial arrangements of nursing homes for elderly people, see Meyer et al. (2017). their former home, their private life is concentrated into one place, a single or sometimes also shared room in the nursing home (Oswald, 2015, p. 709). There is only a fractional amount of private space available for the resident, it is indeed a compression of their space of action. This reduced space for action may be accompanied by a certain loss of participation and increased heteronomy: Besides questions of participative management in the organization of care and nursing processes (Thiele et al., 2002, p. 563), this also refers to the way residents can move within the physical space of a nursing home and how they relate to its physical decor, the material objects in it. In the following, I outline more aspects of the spatial arrangements of nursing homes.

\section{The "Home Paradox" (Martin, 2002, p. 866):}

For some people (the residents) nursing homes are places to live and for other people (the staff) they are places to work, thus becoming two forms of places whose functionalities and rationalities may very well collide and interfere with each other: "Residential organizations may be like a home but, as many scholars note, they are not homes in the usual sense (Diamond, 1992). They are formally administered organizations with budgets, paid staff, trade unions, and structured mealtimes, bathing routines, and rules about coming, going, using the kitchen, and taking medication." (Martin, 2002, p. 867) Goffman (1961, p. 19ff.) also pointed to this paradoxical situation in a total institution.

\section{The Blurring of Boundaries Between the Public and the Private:}

Closely linked to the home paradox is the blurring of boundaries between what is private and what is public within a nursing home for the elderlies (cf. Kaup, 2011). This impacts the way care work itself is perceived by the wider society: "The values, feelings, and interactions that make up the relational essence of care in the private sphere are sometimes devalued, discouraged and even forbidden in the public world. Care givers and the people they care for are pressured by norms, rules and policies of the public world to make care conform to the image of work that predominates in the public world." (Stone, 2000, p. 90) That means, even in the more private spaces within a nursing home (the resident's room for example), the logics of the public world of work permeates intimate (hence-private) caring practices and thereby devaluating it.

\section{The Centrality of Bodies in Nursing (Homes') Practices:}

In comparison to other working and living environments, nursing and caring for elderlies (in nursing homes) are essentially linked to bodily experiences for both, the residents as well as (especially nursing) staff (cf. Twigg, 2000a,b; Wismar, 2007; Hujala and Rassinen, 2011). There is a tendency within nursing to conceive those being cared for primarily as bodies and less as human beings (cf. Twigg, 2004): "Residents' bodies are subjected to the organization's authority and justificational ideology that place (into rooms, beds), control (residents' bodies, time, activities, privileges), and frame/define them (as able 
or dependent) in particular ways" (Martin, 2002, p. 864). ${ }^{8}$ Some of these works mention Goffman's writing on the social construction of the body but the role that materialities play in these processes is still unclear.

\section{Things in Institutionalized Elderly Care}

Until today there is little research concerning the concrete interplay of things and human beings with regard to those contexts in which people (and their bodies) are placed at center stage. This is the case in nursing and caring for elderly people. However, nursing should be of particular interest to the study of materiality as the (material) corporeality plays a constitutive role for nursing in itself (cf. Remmers, 2011). When looking at the role of materiality in nursing (i.a. for elderly people) we take the main premises of phenomenology (cf. Plessner, $1970,1980,1981)$ as the starting point of our investigation: Because of their own bodily materiality people are able to discern and experience material objects. In other words: Realizing the materiality of a thing is only possible because we realize our self as something material (a sensing body which can touch and smell etc.). This material reciprocity is fundamental both for the relationship between things and human beings (cf. Depner et al., forthcoming) as well as for the interactions in the field of nursing (cf. Artner et al., 2017).

Up to date, only little research has been done into the concrete materialities of nursing and care for elderly people or how things shape the processes involved (cf. Artner and Atzl, 2018). Most studies focusing on the material arrangements of nursing practices tend to be evaluative. ${ }^{9}$ Yet, looking at the role of things can advance some of the central concepts or perspectives regarding materiality, especially those that point to the situational embeddedness of materiality in our everyday live and that emphasize the need for close examination of the interactions between things and people on a micro-level. There

\footnotetext{
${ }^{8}$ Martin puts a special emphasis on the role of the staff in old people's homes (OHP): "Guided by administrators and the facility's philosophy, routines, social relations, and cultural ideology, I saw OPH staff socially constructing residents' bodies through talk and practice (Bordo, 1993). They enacted a conception of bodies-as strong or weak, able or disabled, touchable or untouchable, clean or dirty, fair or foul smelling-in ways that shaped residents' perceptions, experiences, and feelings. [...] Often residents cannot control their own bodies relative to place, time, activity, or function. For example, they cannot go for a stroll at will, make a cup of tea at 2 a.m., or walk the dog at sunrise, as they could 'at home.' Some cannot move from their beds or use the toilet without help from staff. They are subjected to the power and discipline of a formal organization that manages their use of space, social relations, behavior, and bodily functions" (Martin, 2002: 867).

${ }^{9}$ Within health care work instrumental perspectives on materialities dominate; for example, research on the functionality and the safety and well-being of patients (cf. Pearson et al., 2001; Petzäll et al., 2001; Barnes, 2006; Dijkstra et al., 2006; Boldy et al., 2007) or research on the design of care environments, especially in dementia care (cf. Day et al., 2000; Falk et al., 2009; Topo and Kotilainen, 2009). From the point of view of practice, objects play a key role in different issues in the treatment and care of elderly people, especially those who suffer from dementia. All in all, the discussion about how things and devices are involved in the care and in the lives of elderly people tends to be critical, if not evaluative (cf. Dominguez-Rue and Nierling, 2016). The fact that there are hardly any or at least not enough studies on the effectiveness of objects and technological devices in care for old people has been criticized (Gibson et al., 2016). The involvement of objects in care work has recently become more relevant (cf. Artner and Atzl, 2016; Artner et al., 2017; Böhringer et al., 2017).
}

is an increasing need to empirically look at the ways in which things are situationally used and operated. It is claimed that we need to look at the socio-cultural context of the usage of things. But the factual role that a thing has and the meaning it receives can only be revealed with regard to the way it is handled and used: The meaning of a thing is not fixed, it may change depending on the context and the social situation (cf. Hahn, 2005, 2015; Korff, 2005). This is where my research on things in elderly care is located.

The aspect of the compression of private space is of special importance in my own research on the material arrangements of nursing homes seen as total institutions in the sense of Goffman: The less space there is available to live in, the more important it is how this living space is actually filled. If we take into account Goffman's dictum of the "identity-kit" (1961: 27) ${ }^{10}$ and especially the severe consequences if one looses the control over her/his personal belongings, this means that we have to look at how the compressed private space is filled with personal or institutional things. This perspective is informed by a relational approach to material objects and to space which is informed by Goffman (cf. 1959, 1974), who repeatedly spoke about how places are created through the placement of people and things, the latter of course being placed by people. Through that placement, places maintain a symbolic effectiveness that extends beyond their physical here and now. This idea also points to the way things are understood here-as products of social interaction. Besides the possibility of a symbolic reference that goes beyond a given situation in which a material object is used or referred to, this also means that its symbolic meaning is not fixed but has to be constantly re-produced. This is also one reason for the variety of interpretations, as things can be and are used in different situations and settings differently by people with quite different backgrounds. Yet, I would still assert that there are certain symbolic properties of material objects that are in a way fixed, at least to one person and at least for a certain period of time. This means that things may be used to reproduce certain ideas about a person. Here I refer to Goffman's term of the "identity kit" (1961: 27): For Goffman, certain things might serve as equipment for one's identity. If one loses the right to own property, this might lead to something which Goffman calls the loss of one's status as a civilian (cf. Goffman, 1961: 24) or the "passage from civilian to patient status" (Goffman, 1961: 127). The loss of ones identity kit is especially precarious in a situation in which the private and public is blurred through certain spatial and material arrangements-as is the case in many nursing homes.

This brings us back to the concept of the total institution. According to Goffman, the dispossession of personal belongings is another characteristic of a total institution: through the deprivation of personal possessions the member of a total institution loses "control over the guise in which he appears

\footnotetext{
${ }^{10}$ Goffman defines this as the following: "One set of the individual's possessions has a special relation to self. The individual ordinarily expects to exert some control over the guise in which he appears before others. For this he needs cosmetic and clothing supplies, tools for applying, arranging, and repairing them, and an accessible, secure place to store these supplies and tools-in short, the individual will need an 'identity kit' for the management of his personal front." (1961: 27).
} 
before others (...), thus suffering a personal defacement" (Goffman, 1961: 20). However, in a nursing home, the resident clearly has much-advanced rights to own property. But, as shown in recent studies (cf. Depner, 2015), in practice elderly people moving to a nursing home have to and do (or want to) in fact leave the vast majority of their personal belongings behind. The compression of private space goes along with the decrease in personal belongings, in the things people own and can identify with. Furthermore, there is a tendency not only to uniformly design the interiors of resident's private rooms, but to homogenize caring practices and the means to accomplish them (Andrews et al., 2005, p. 111).

As I now want to demonstrate with regard to my own research, in nursing homes we not only find fewer personal things; we also find that the compressed private spaces of the residents are somehow permeated by the things of the institution of a nursing home-things that make an institution and that somehow institutionalize the residents within it. When living under the conditions of a (moderate) total institutions like a nursing home for elderly people, the relationship between oneself and one's things changes. By adopting Goffman's ideas on the constitution of the self in total institutions I will discuss how this affects residents of nursing homes already on the level of the materialities of their everyday life. By looking at its material and spatial arrangements, we can draw a much more accurate figure on the functioning of a nursing home as a (moderate) total institution than the literature on nursing homes provides so far.

\section{EMPIRICAL EXAMPLES OF THE ROLE OF NURSING THINGS IN CARE FOR ELDERLY PEOPLE}

\section{Research Design}

Between 2014 and 2016 I conducted ethnographic research a nursing homes for elderly people in Germany. ${ }^{11}$ An examination of the micro-level of nursing interactions between people and things through mainly participant observation, ${ }^{12}$ this study focused on the role that things can have in nursing practice. I was interested in how things help (or hinder) the creation of the socially shared realities, self-evident truths and interpretational schemes which influence the field of care for elderly people. My inductive research project mainly examined the question of how things are used to produce and reproduce not just social order in the form of powerful social relationships, but also notions of normality (including those which influence normative discourses). This is why I looked beyond specific

\footnotetext{
${ }^{11}$ This research was mainly part of the project called "Care and Things", as mentioned in footnote 2 .

${ }^{12}$ Many studies focusing on the question whether a nursing home for the elderly is in fact a total institution rest upon surveys (interviews) and only few on other observational (ethnographic) methods which focus on face-to-face interactions of the participants involved [with exception by i.a. Martin (2002) on aesthetic and bodily experiences, Koch-Straube (2003) on everyday life, or Hujala and Rassinen (2011) on organizational asthetics and materialities of management]. In some studies this caused methodological problems, as i.a. most of the residents interviewed showed a tendency to be overly optimistic and were reluctant to express criticism (Clark and Bowling, 1990: 1205; cf. Peace et al., 1979).
}

situational uses of material objects within interactions and drew conclusions about general everyday workflows, relationships and moral concepts of care in practice. In addition to the participant observations, I analyzed instruction manuals and textbooks, and carried out semi-structured narrative interviews with nursing staff. In this paper I will primarily introduce situational photographs of inpatient care settings to demonstrate my argument. What the figures illustrate will be discussed with regard to my ethnographic data (mainly participant observations and interviews).

\section{Object-Based Compression of Private Space}

The first finding about the effect of the material and spatial arrangements in a nursing home for elderly people refers to the blurring of boundaries between the private and the public. Through the placement of things there is not only a compression of private spaces for residents but it also reduces their possibilities of constructing their selves through their very own "identity kit" (Goffman, 1961, p. 21). Let me first demonstrate this with a figure of a resident's room in one of the nursing homes in which I conducted my research.

In Figure 1 we see a private room, in which we find personal belongings of the resident as well as things that are provided and owned by the nursing home. We see personal things, such as figures on the wall or the photographs in the back, the dolls on the couch or the little figurine of an angel, the paper star hanging from the ceiling or two clocks. Some furniture, like the couch, the TV stand, the floor lamp and the bed table, also belong to the resident. The two jackets on the couch are two visitors' (the resident's son and grandson). Besides that, we also see many things that belong to the nursing home, for example the bed, which had to be the same model in all residents' private rooms: a special electronic nursing bed. We see also some things which are more clearly related to nursing: among other things we see a feeding cup, a bottle holder for an intravenous pole, a disposable incontinence sheet on the bed or an emergency bell next to it.

Looking at the arrangement of material objects in this room, we see a hybrid between a private space and a space of nursing or the nursing home, with things used or organized by nursing staff.

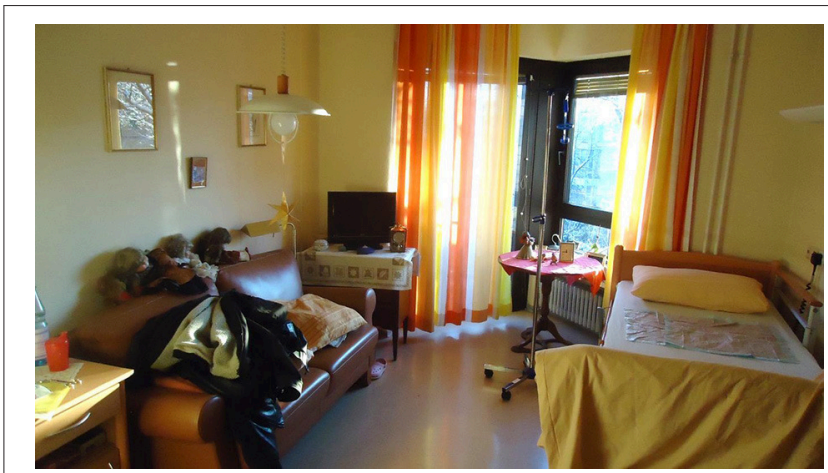

FIGURE 1 | Private room of a resident of a nursing home, taken by Artner 2015. 
Here, the compression of private space as discussed by Goffman becomes apparent: this is a room where residents sleep, watch television, relax but where also their personal care, therapeutic or medical treatments take place. Furthermore, even the personal belongings of the residents that we see here can only to a very limited extent be conceptualized as part of a household, as an autonomously and managed site of civic privacy and selfdetermination (Goffman, 1961, p. 17ff.) as they are arranged and managed by the staff, especially the cleaning staff on a daily basis. This affects the status of the personal things as they are made part of the institution by formal procedures, e.g., the cleaning and washing routines: resident's cloths are tagged with a name badge, there are fixed times when clothes are to be washed, and it is usually the nurses or the cleaning staff that decide this.

This, however, as my observations showed, impacted the residents in certain ways, as the protection of personal belongings became of importance. Some residents for example developed strategies of hiding cloths from nurses and cleaning staff as they themselves wanted to decide when a t-shirt has to be perceived as dirty and when not. The staff on the other hand then waited and seized those moments when they could remove the T-shirt they deemed as being in need of cleaning without the resident noticing it. In a similar vein, there were cases in which nurses were not allowed to touch assistive appliances like a wheelchair. These requests were accommodated but explained to me as very "stubborn" behavior. Another example that points to the importance of managing one's own room or at least the personal belongings in it could be a resident who presented himself as more physically fit than others: he invited me to his private room to show me his impressive collection of tin soldiers. While he showed me around in his room he very proudly talked about how he managed the cleanliness of his room almost autonomously and that he even made his own bed.

\section{Secondary Adjustment Through Things}

When looking at the micro-level of social interaction we find many more strategic usages and negotiation processes involved. For example, there were strategies by the residents to subvert things that were used for nursing, respectively owned by the nursing home: for example, when residents removed the disposable incontinence sheet from the bed or when they took the remote control of the nursing bed. These moves were often prevented by the nurses who tried to demonstrate to them that these things were not to be touched or handled by residents but by the staff only. Another kind of subversive usage of things was the throwing away of things: it did occur quite regularly that residents pushed down their plastic feeding cups from the table in the dining room. Staff explained this behavior as a sort of "playing" with the feeding cups, thereby trivializing these actions of the residents. Yet, they did not mention the reasons for this play and why it happens so often, or if maybe this play was a mode to express discomfort or protest. A third way to subversively use things is by not using or ignoring themor by excessively employing them: the emergency call system which connected the emergency bells (i.a. in the private rooms) with the cordless telephones every staff member carried with themselves serves as a good example here. This system was used by some residents excessively whereas other residents almost always ignored the emergency bells and would rather loudly call for nursing staff to come to them. Whereas, excessive emergency calls were not sanctioned, residents who disused the emergency bell were rebuked.

Be it pride over one's possessions, the tactic to withhold things (like clothes) or to take-over things meant to be used by nursing staff, or be it to excessively overuse, ignore or misuse things (e.g., throwing away feeding cups), whatever the case may be, all these incidents exemplify what Goffman termed "secondary adjustment" in total institutions: "In every social establishment participants use available artifacts in a manner and for an end not officially intended, thereby modifying the conditions of life programmed for these individuals. A physical reworking of the artifact may be involved, or merely an illegitimate context of use [...]. While this transformation process underlies many complex practices, it can be most clearly seen where the practitioner is not involved with others (except in learning and teaching the technique), he alone consuming what he just produced." (Goffman, 1961, p. 207f.) Practices of secondary adjustments are important for the (re-)establishment of a sense of self in light of the continuous mortification of the self in a total institution. As this mortification takes place through dispossessions of personal belongings, secondary adjustment also means to keep or regain certain material objects like "small, illicit, talisman-like possessions that inmates use as symbolic devices for separating themselves from the position they are supposed to be in" (Goffman, 1961: 307). But the reaction of the staff to these not officially intended ways of applying things also shows how their interpretation of the negotiation process they had with residents about the placement and usage of things eventually approved their status in having the last word over those very things. The subversive actions of the residents were conceded to them by the staff. A limited acceptance of these kinds of insurgent behavior is an important part of what Goffman had in mind with his concept of secondary adjustment in total institutions.

\section{Material and Spatial Institutionalization of an Elderly Self}

A third finding points to different ways in which the institutionalization of the resident's self is achieved through specific ways of placing (institutional) things. To illuminate this, let us take a closer look at the second part of a private room, the bathroom, which in this case is shared by two residents.

In this bathroom we see only few personal things. In Figure 3 we see some personal hygiene products owned by the two residents that share this bathroom which are arranged on top of or besides the lavatory: A shampoo and a body wash bottle, two canned crèmes, two perfumes and a deodorant, a soap in small plastic container, a nail brush as well as two toothbrushes, toothpaste and two bottles of mouthwash. These are used by two different persons living in the nursing home who share this space of intimacy. All the other things in the bathroom that we see in Figures 2, 3 (which shows a broader part of the bathroom) are provided and owned by the nursing home and for the most part only used by nurses. Even terrycloth or disposable washcloths, 


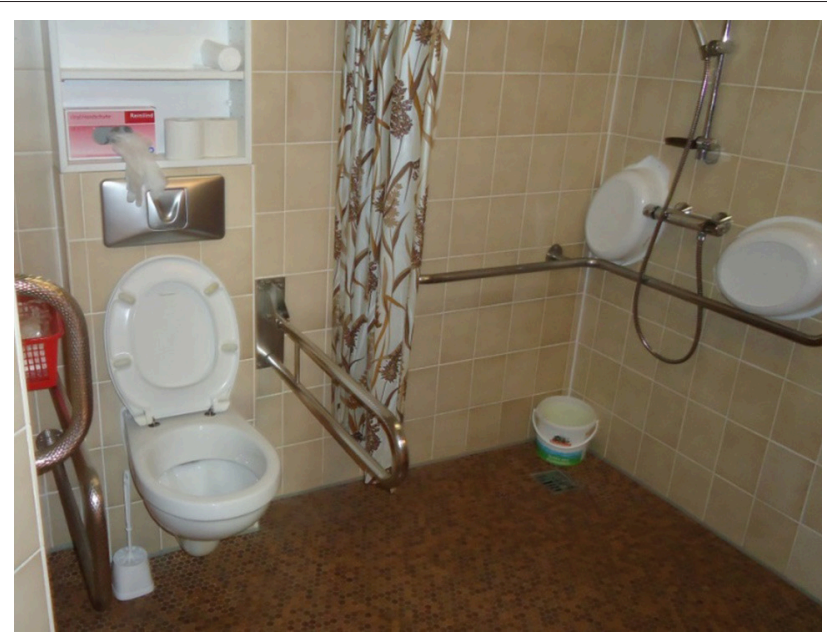

FIGURE 2 | A shared private bathroom of two residents, taken by Artner 2015.

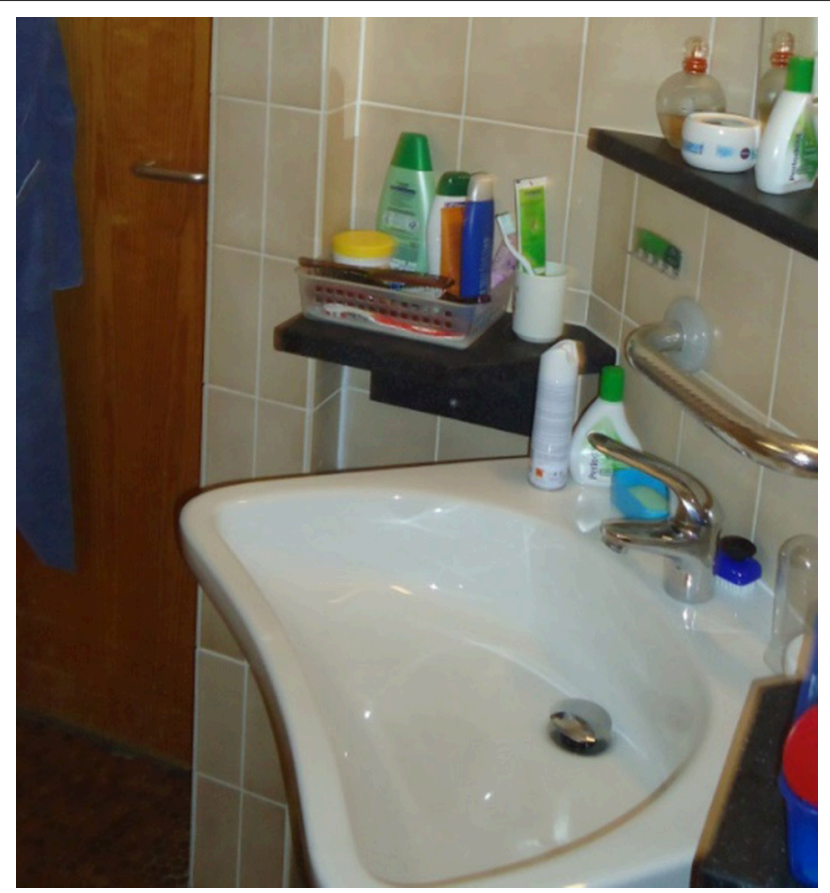

FIGURE 3 | A shared private bathroom of two residents, taken by Artner 2015.

which we can only see suggestively here on the shelf, were mostly used by nurses who often gave them to residents while they helped them to wash themselves. In many other bathrooms I saw a very similar figure. Nursing things were omnipresent: almost everywhere, I saw disposable gloves or disposable washing cloths and other things which were only or mostly operated by nursessuch as the small washbasins we see here; these were if at all handed to residents and cleaned after use by the nurses.

What does this omnipresence tell us? Let us, for instance, have a closer look at the disposable gloves. In this respective nursing home these were available to nurses in different sizes in every private room, mostly but not only in the bathrooms.
These gloves were only used by nurses; no "misuse" by residents was reported. Residents did not claim these as something they operated with; they were not perceived as being part of their belongings even though they were part of their private rooms. Moreover, the gloves we see here are the property of the nursing home and somehow of the residents' rooms, but not of the residents themselves. The residents have the gloves in their private rooms or bathrooms but do not own them, the nursing home does. The staff seem to trust the residents not to "misuse" them.

The usage of gloves by nurses, for example when they helped residents with their personal hygiene, was not brought up, not spoken about, during these interactions. Their usage happened en passant, somehow naturally. Disposable gloves were not only used in most of the nursing processes I observed, it was mostly the first thing that nurses put on and the last thing they pulled off, when the interaction with a respective resident ended.

Disposable gloves can be described as a basic nursing thing or as being "insignia of nursing," as Koch-Straube called it (2003, p. 209, translation by the author). These are things which are especially designed for nursing and the usage of which is to be primarily controlled by nursing staff. Besides disposable gloves, these things can be disposable incontinence sheets, lifter technologies, toilet chairs, disposable washcloths, medical ventilators and so on (Kollewe et al., 2017, p. 30, cf. Depner and Kollewe, 2017). Some of these things can be seen in the figures above. As already mentioned, their deployment was mostly conducted or at least supervised by nursing staff.

They help to create a situation, such as helping a resident to shower or go to the toilet as a nursing situation. From all interactions in the bathing rooms observed, the nurses were the ones that gave instructions on what residents had to do and how they had to do it. In many cases, this happened non-verbally, mainly by handing over things like standardized cotton washing cloths which were provided by the nursing home. Especially in bathing situations, in which most residents depended on the help of the nurses, and in which the utilization of standardized things was highly common, there were almost no negotiations taking place about how things should be used.

However, these things also shape the nursing home as an institution: These were standardized things, validated by the German statutory health insurance's medical technical aids register (in German: Hilfsmittelverzeichnis der Gesetzlichen Krankenversicherungen) and in general provided by the nursing home management. There is rarely the chance for staff and even less for residents to participate in the decision-process for or against a specific product. Even though used on a daily basis by and for residents, the way these things were acquired did not necessarily resonate with the need of the residents. In a similar vein, (Hujala and Rassinen, 2011, p. 443) discovered that "operational decision-making about purchasing equipment that makes daily care work easier also seems to ignore the end users."

As a result, the omnipresence of these nursing things in the private rooms and the bathrooms of the residents marks these rooms and their inhabitants as part of an institutional nursing arrangement: the private rooms, including the bathrooms, are 
not only private places for the residents to live but also places where nurses work, where the nursing home's staff organize nursing and care work. It is an institutionalized private room, institutionalized through these particular material and spatial arrangements, as especially obvious with regard to the photographs I showed as examples. In the following, I want to conclude on my perspective on the material and spatial arrangements of these processes of institutionalization.

\section{CONCLUSION}

In the last part I want to reflect on the question how a perspective on the material and spatial arrangements of a nursing home can contribute to the literature on nursing homes for elderly people as total institutions. Goffman argues that social interaction is a kind of theatrical performance (1959: preface). With regard to this we can assert that the private room in a nursing home which we have seen in this article is the front stage, while the bathroom resembles more a backstage area. Not everybody enters the bathroom. By way of contrast, the private room is staged, as if it is meant to tell us something about its inhabitant: someone who enjoys paintings, who likes decorative elements, such as puppets or angel figurines. Most of us would guess that this particular resident is a woman, which in this case is correct. So these things also help with doing gender. However, the distinction between front and backstage is also blurred-by things: we see some institutionalized nursing things in the private room of the resident as well as the bathroom. Thus, the presentation of the resident's self is also a self that lives in a nursing context, that receives and/or is in need of care, of support. Yet this is a person that is not able or allowed to use certain things, such as disposable gloves. Things which are not owned or appropriated by them, which are used and controlled by others, by the staff of the nursing home.

Looking at another premise of Goffman's work, which is central to his conceptualization of a total institution, the institutionalizing effect of material objects becomes apparent: Everyday things which are needed for one's "identity kit" (Goffman, 1961, p. 27)-like clothes-are only available to a limited extent for a self-determined presentation of one's self. What we see is a certain kind of heteronomy which is mediated by the

\section{REFERENCES}

Alworth, D. J. (2014). Melville in the Asylum: literature, sociology, reading. Am. Liter. History 1-28. doi: 10.1093/alh/aju019

Amrhein, L. (2005). "Stationäre Altenpflege im Fokus von Machtbeziehungen und sozialen Konflikten," in Soziologie der Pflege: Grundlagen, Wissensbestände und Perspektiven, eds Schroeter, K. R. and Rosenthal T. (Weinheim; München: Juventa), 405-426.

Andrews, G. J., Holmes, D., Poland, B., Lehoux, P., Miller, K. -L., Pringle, D., et al. (2005). 'Airplanes are flying nursing homes': geographies in the concepts and locales of gerontological nursing practice. Int. J. Older People Nursing 14, 109-120. doi: 10.1111/j.1365-2702.2005.01276.x

Appadurai, A. ed. (1986). "The social life of things," in Commodities in Cultural Perspective. (Cambridge: Cambridge University Press) material and spatial arrangements of the nursing home: By taking a closer look at things and how they are arranged and used, we can reconstruct how the residents of a nursing home are subjected to the procedures and objectives of the institution. The material and spatial arrangements we saw point to certain kinds of ways of subjugation, in which a nursing home as a (moderate) total institution brings their residents to submit themselves to it. This leads to the residents of a nursing home themselves being created as a somehow institutionalized self. Applying a material studies perspective on Goffman's idea of a total institution demonstrates how things make for an institution as they help to adjust its members to its very functioning.

Coming back to my initial questions: Do things matter? And why should we even care about things? As we saw with regard to the way things are spatially arranged and used in the private rooms of residents of a nursing home in Germany, things do indeed matter. In this example, they matter by helping to create a "totalizing" environment. I would like to conclude by claiming that we should indeed care about things, as there are some effects that might be unintended and often overseen. Pointing to the way things can matter-be it positive or not-is of crucial importance, especially in the case of people living in nursing homes.

How this takes shape in the longer term should be subject to future research. In the light of an aging society (at least in Germany, where my research took place) and the increase in age-related forms of dementia which will lead to further cases of inpatient long-term care, future studies should take a more systematic look at the correlations between things and the construction of the self over a longer period of time. Part of this long-term research should be (1) to debug the advantages and limitations of researching how the presentation of the self can be mediated by things especially in the case of dementia and (2) to illuminate subversive strategies by residents to resist subjugating practices mediated by things. This means, future research should take a closer look at how people escape the material and spatial arrangements of a (moderate) total institution.

\section{AUTHOR CONTRIBUTIONS}

The author confirms being the sole contributor of this work and has approved it for publication.
Artner, L., and Atzl, I. (2016). Pot and Power: The Role of the Nonhuman in a Very Human Business. On_Culture: The Open Journal for the Study of Culture 2 Available online at: urn:nbn:de:hebis:26-opus-123553

Artner, L., and Atzl, I. (2018). Material Care Studies-Objekttheoretische Zugänge zu Pflege und Care. Workingpaper. Hildesheim: Universitätsverlag Hildesheim, 12 pages.

Artner, L., Atzl, I., Depner, A., Heitmann-Möller, A., and Kollewe, C. eds. (2017). Pflegedinge-Materialitäten in Pflege und Care. Bielefeld: Transcript.

Barnes, S. (2006). Space, choice and control, and quality of life in care settings for older people. Environ. Behavior. 38, 589-604. doi: 10.1177/0013916505281578

Böhringer, D., Artner, L., and Richter, J. (2017). "Working With Objects in Dementia Care", presentation at the Congress of the American Sociological Association (Section "Ethnomethodology and Conversation Analysis") (Montréal, OC: Palais des Congrès de Montréal). 
Boldy, D., Davies, S., and Grenade, L. (2007). Quality of life, quality of care and resident satisfaction in nursing homes. J. Care Services Manage. 1, 1-13. doi: 10.1016/j.shaw.2017.12.002

Bordo, S. (1993). Unbearable Weight: Feminism, Western Culture, and the Body. Berkeley, CA: University of California Press.

Clark, P., and Bowling, A. (1990). Quality of everyday life in long stay institutions for the elderly. An observational study of long stay hospital and nursing home care. Soc. Sci. Med. J. 30, 1201-1210. doi: 10.1016/0277-9536(90)90260-Y

Dathe, S. (2014). "Alter(n) und Altersbilder in Pflegeheimen," in Der ungewisse Lebensabend? Alter(n) und Altersbilder aus der Perspektive von (Un-) Sicherheit im Historischen und Kulturellen Vergleich, ed H. Pelizäus-Hoffmeister (Wiesbaden: Springer VS.), 167-181.

Davies, D. M., and Snaith, P. A. (1980). The social behaviour of geriatric patients at mealtimes: an observation and an intervention study. Age Ageing 9, 93-99. doi: 10.1093/ageing/9.2.93

Day, K., Carreon, D., and Stump, C. (2000). The therapeutic design of environments for people with dementia. A review of the empirical research. Gerontologist 40, 397-416. doi: 10.1093/geront/40.4.397

Depner, A. (2015). Dinge in Bewegung - zum Rollenwandel materieller Objekte: Eine ethnographische Studie über den Umzug ins Altenheim. Bielefeld: Transcript.

Depner, A., Artner, L., Kollewe, C., Atzl, I., and Heitmann-Möller, A. (forthcoming). "pflegedinge': beziehungsarbeit und objektbeziehungen in pflegesettings," in Beziehungskisten - Sozialität und Soziabilität durch Dinge, ed J. Lang, and M. Fineder (Wiesbaden: Springer VS).

Depner, A., and Kollewe, C. (2017). "High-tech und handtaschen. Gegenstände und ihre rolle in der pflege und der unterstützung älterer und alter Menschen," in Alter(n) als soziale und kulturelle Praxis. Ordnungen - Beziehungen Materialitäten, ed C. Endter, and S. Kienitz (Bielefeld: transcript), 301-326.

Deutsche Forschungsgemeinschaft (DFG) (2013). Sicherung guter wissenschaftlicher Praxis. Denkschrift. Empfehlungen der Kommission "Selbstkontrolle in der Wissenschaft". Weinheim: WILEY-VCH.

Deutsche Forschungsgemeinschaft (DFG) (2014). Wissenschaftsfreiheit und Wissenschafts-verantwortung. Empfehlungen zum Umgang mit sicherheitsrelevanter Forschung. Bonn: DFG.

Diamond, T. (1992). Making Gray Gold: Narratives of Nursing Home Care. Chicago, IL: University of Chicago Press.

Dijkstra, K., Pieterse, M., and Pruyn, A. (2006). Physical environmental stimuli that turn healthcare facilities into healing environments through psychologically mediated effects: systematic review. J. Adv. Nurs. 56, 166-181. doi: 10.1111/j.1365-2648.2006.03990.x

Dominguez-Rue, E., and Nierling, L. (eds.). (2016). "Ageing and technology," in Perspectives From the Social Sciences, (Bielefeld: transcript).

Falk, H., Wijk, H., and Persson, L. (2009). The effects of refurbishment on Residents' quality of life and wellbeing in two swedish residential care facilities. Health Place 15, 717-724. doi: 10.1016/j.healthplace.2008.11.004

Foldes, S. (1990). "Life in an Institution: a sociological and anthropological view", in Everyday Ethics: Resolving Dilemmas in Nursing Home Life, ed R. Kane, and A. L. Kaplan (New York, NY: Springer), 21-36.

Frers, L. (2010). "Automatische irritationen. Überlegungen in video zur initativentfaltung der dinge," in Die Sprache der Dinge: Kulturwissenschaftliche Perspektiven, ed Gesellschaft für Ethnographie e.V./Elisabeth Tietmeyer/Claudia Hirschbergerandere (Münster: Waxmann), 195-202.

Gebert, A. J., and Kneubühler, H.-U. (2001). Qualitätsbeurteilung und Evaluation der Qualitätssicherung in Pflegeheimen: Plädoyer für ein gemeinsames Lernen. Bern/Göttingen: Huber.

Gesler, W. (1992). Therapeutic landscapes: medical issues in the light of the new cultural geography. Soc. Sci. Med. 34, 735-746. doi: 10.1016/0277-9536(92)90360-3

Gibson, G., Newton, L., Pritchard, G., Finch, T., Brittain, K., and Robinson, L. (2016). The provision of assistive technology products and services for people with dementia in the United Kingdom. Dementia 15, 681-701. doi: $10.1177 / 1471301214532643$

Godlove, C., Richard, L., and Rodwell, G. (1981). Time For Action. An Observational Study of Elderly People in Four Different Care Environments. Community Care, (Sheffield: University of Sheffield Joint Unit for Social Services Research). Social Services Monographs: Research in Practice

Goffman, E. (1959). The Presentation of Self in Everyday Life. New York, NY: Doubleday Anchor.
Goffman, E. (1961). Asylums. Essays on the Social Situation of Mental Patients and Other Inmates. New York, NY: Doubleday Anchor.

Goffman, E. (1974). Das Individuum im öffentlichen Austausch. Mikrostudien zur öffentlichen Ordnung. Frankfurt am Main: Suhrkamp.

Goodman, B. (2013). Erving goffman and the total institution. Nurse Edu. Today 3, 81-82. doi: 10.1016/j.nedt.2012.09.012

Hahn, H. P. (2005). Materielle Kultur. Eine Einführung. Berlin: Reimer.

Hahn, H. P. (2014). Materielle Kultur. Eine Einführung. 2nd Edn. Berlin: Reimer.

Hahn, H. P. (2015). "Der Eigensinn der der Dinge. Einleitung," in Vom Eigensinn der Dinge. Für eine neue Perspektive auf die Welt des Materiellen, ed H. P. Hahn (Berlin: Neofelis), 9-56.

Hämel, K. (2010). Öffnung und Engagement. Altenpflegeheime zwischen staatlicher Regulierung, Wettbewerb und zivilgesellschaftlicher Einbettung. Dissertation, University of Gießen (Gießen).

Harper Ice, G. (2002). Daily life in a nursing home. Has it changed in 25 years? J. Aging Stud. 16, 345-359. doi: 10.1016/S0890-4065(02)00069-5

Heinzelmann, M. (2004). Das Altenheim - immer noch eine "Totale Institution"? Eine Untersuchung des Binnenlebens zweier Altenheime. Dissertation, University of Göttingen (Göttingen).

Hook, W. F., Sobald, J., and Oak, J. C. (1982). Frequency of visitation in nursing homes: patterns of contact across the boundaries of total institutions. Gerontologist 22, 424-428. doi: 10.1093/geront/22.4.424

Hujala, A., and Rassinen, S. (2011). Organization aesthetics and nursing homes. $J$. Nurs. Manag. 19, 439-448. doi: 10.1111/j.1365-2834.2011.01193.x

Jenkins, J., Felce, D., Lunt,B., and Powell, L. (1977). Increasing engagement in activity of residents in old people's homes by providing recreational materials. Behav. Res. Ther. 15, 429-434.

Kahn, D. L. (1999). Making the best of it: adapting to the ambivalence of a nursing home environment. Qual. Health Res. 9, 119-132. doi: $10.1177 / 104973299129121631$

Kaup, M. L. (2011). The Significance of the Door in Nursing Homes: a Symbol of Control in the Domestic Sphere. Available online at: http://krex.ksu.edu

King, R. D., and Raynes, N. (1968). An operational measure of inmate management in residential institutions. Soc. Sci. Med. 2, 41-53. doi: 10.1016/0037-7856(68)90100-5

King, R. D., Raynes, N., and Tizard, J. (1973). Patterns of Residential Care. (London: Routledge \& Kegan Paul)

Koch-Straube, U. (2003). Fremde Welt Pflegeheim. Eine ethnologische Studiem, 2nd Edn. Bern: Hans Huber.

Kollewe, C., Heitmann-Möller, A., Depner, A., Atzl, I., and Artner, L. (2017). "Pflegedinge - Materialitäten in Pflege und Care. Theoretischer Rahmen und interdisziplinärer Ansatz", in Pflegedinge - Materialitäten in Pflege und Care, eds L. Artner, I. Atzl, A. Depner, A. Heitmann-Möller, and C. Kollewe (Bielefeld: Transcript), 15-44.

Korff, G. (2005). "Sieben Fragen zu den Alltagsdingen", in Alltagsdinge. Erkundungen der materiellen Kultur, ed G. König (Tübingen: TVV), 29-42.

Löw, M. (2001). Raumsoziologie. Frankfurt: Suhrkamp.

Ludwig, A. (2011). "Materielle Kultur. Version: 1.0," in Docupedia-Zeitgeschichte, Available online at: http://docupedia.de/zg/ludwig_materielle_kultur_v1_de_ 2011 (Accessed May 5, 2011)

Martin, P. Y. (2002). Sensations, Bodies, and the 'Spirit of a Place': aesthetics in residential organizations for the elderly. Human Relations 55, 861-885. doi: 10.1177/0018726702055007544

Meyer, N., Steinberg, D., and Burkart, G. (2017). "Multiprofessionalität und Wohn-Raum. Vorarbeiten zu einer komparativen (Berufs-)Gruppenforschung in der sozialen Welt Altenheim", in Pädagogisch institutionelles Wohnen: Zur Relevanz einer erziehungswissenschaftlichen Perspektive auf Wohnen, ed M. Meuth (Wiesbaden: Springer VS), 267-287.

Miller, D. (1987). Material Culture and Mass Consumption. Oxford and Cambridge, M.A.: Basil Blackwell.

Miller, D. (2005). "Materiality: an Introduction", in Materiality (Politics, History and Culture), ed D. Miller (London: Durham), 1-50.

Natter, W., and Jones, L. P. (1997). "Identity, Space, and other Uncertainties," in Space and Social Theory: Interpreting Modernity and Postmodernity, ed G. Benko, and U. Strohmayer (Oxford: Blackwell), 141-161.

Oswald, F. (2015). Möglichkeitsraum als Raum. Anmerkungen aus ökogerontologischer Perspektive. Zeitschrift für Gerontologie und Geriatrie 8, 707-710. doi: 10.1007/s00391-015-0977-x 
Pavolini, E., and Ranci, C. (2008). Restructuring the welfare state: reforms in long-term care in western european countries. J. Eur. Soc. Policy 18, 246-259. doi: $10.1177 / 0958928708091058$

Peace, S., Hall, J. F., and Hamblin, J. R. (1979). The Quality of Life of the Elderly in Residential Care. Survey Research Centre Report No. I. Department of Applied Social Studies. Polytechnic of North London.

Pearson, A., Baker, H., Walsh, K., and Fitzgerald, M. (2001). Contemporary Nurses' Uniforms - History and Traditions. J. Nurs. Manag. 9, 147-152. doi: 10.1046/j.1365-2834.2001.00207.x

Petzäll, K., Berglund, B., and Lundberg, C. (2001). The staff's satisfaction with the hospital bed. J. Nurs. Manag. 9, 51-57. doi: 10.1111/j.1365-2834.2001.00189.x

Pinch, T. (2008). Technology and Institutions: living in a material world. Theor. Soc. 37, 461-483. doi: 10.1007/s11186-008-9069-x

Plessner, H. (1970). Philosophische Anthropologie. Frankfurt am Main: Fischer.

Plessner, H. (1980). Gesammelte Schriften, volume 3, ed G. Dux Frankfurt am Main: Suhrkamp.

Plessner, H. (1981). Gesammelte Schriften, volume 4, ed G. Dux Frankfurt am Main: Suhrkamp.

Pöschel, K. G. (2013). Die Auswirkungen der Risikopotenzialanalyse auf ein Altenund Pflegeheim als Totale Institution. Dissertation, University of Osnabrück, Osnabrück.

Posenau, A. (2014). Analyse der Kommunikation zwischen dementen Bewohnern und dem Pflegepersonal während der Morgenpflege im Altenheim. Mannheim: Verlag für Gesprächsforschung.

Prahl, H.-W., and Schroeter, K. R. (1996). Soziologie des Alterns. Eine Einführung. Stuttgart: UTB.

Quirk, A., Lelliot, P., and Seale, C. (2006). The permeable institution: an ethnographic study of three acute psychiatric wards in london. Soc. Sci. Med. 63, 2105-2117. doi: 10.1016/j.socscimed.2006.05.021

Remmers, H. (2011). "Pflegewissenschaft als transdisziplinäres Konstrukt. Wissenschaftssystematische Überlegungen: eine einleitung," in Pflegewissenschaft im interdisziplinären Dialog, ed H. Remmers (Göttingen: V\&R unipress), 7-47.

Richard, M. P. (1986). Goffman Revisisted: relatives vs. Admin. Nurs. Homes Qualit. Sociol. 9, 321-338. doi: 10.1007/BF00988462

Roth, G. (2007). Dilemmata der Altenpflege: die logik eines prekären sozialen Feldes. Berliner J. für Soziol. 1, 77-96. doi: 10.1007/s11609-007-0005-0

Schmidt, R. (1999). "Pflege als Aushandlung. Die neuen pflegeökonomischen Steuerungen”, in Die neue Pflege alter Menschen, eds T. Klie, and R. Schmidt (Bern: Huber), 33-91.

Schneekloth, U., and Wahl, H. W. (2007). "Möglichkeiten und Grenzen selbständiger Lebensführung in stationären Einrichtungen (MuG IV)
- Demenz, Angehörige und Freiwillige, Versorgungssituation sowie Beispielen für, Good Practice"," in des Forschungsprojekts im Auftrag des Bundesministeriums für Familie, Senioren, Frauen und Jugend. München: Integrierter Abschlussbericht

Scott, S. (2010). Revisiting the Total Institution: performative regulation in the reinventive institution. Sociology 44, 213-231. doi: 10.1177/0038038509357198

Stone, D. (2000). "Caring by the Book," in Care Work: Gender, Labor, and Welfare States, ed M. Harrington Meyer (New York, NY: Routledge), 89-111.

Strauch, B. (1978). “Altenheim und Altenrolle," in Alter als Stigma oder Wie Man Alt Gemacht Wird, ed J. Hohmeier, and H.L. Pohl, (Frankfurt: Suhrkamp), 102-137.

Thiele, C., Feichtinger, L., Baumann, U., Mitmansgruber, M., and Somweber, M. (2002). Der Umzug ins Seniorenheim - Erfahrungen von Senioren und Angehörigen. Zeitschrift für Gerontologie und Geriatrie 35, 556-564. doi: 10.1007/s00391-002-0067-8

Thomas, W. H. (1994). The Eden Alternative. St. Louis: University of Missouri.

Topo, P., and Kotilainen, H. (2009). "Designing enabling environments for people with dementia, their family carers and formal carers", in Dementia, Design and Technology, ed P. Topo, and B. Östlund (Amsterdam: IOS Press), 45-60.

Townsend, P. (1962). The Last Refuge. London: Routledge \& Kegan Paul.

Twigg, J. (2000a). Bathing-the Body and Community Care. New York, NY: Routledge.

Twigg, J. (2000b). Carework as form of bodywork. Ageing Soc. 20, 389-411. doi: $10.1017 /$ S0144686X99007801

Twigg, J. (2004). The Body, Gender, and Age: feminist insights in social gerontology. J. Aging Stud. 18, 59-73. doi: 10.1016/j.jaging.2003.09.001

Voyer, P., Verreault, R., Cappeliez, P., Holmes, D., and Mengue, P. (2005). Symptoms of psychological distress among elderly residents in Canadian longterm care. Aging Mental Health 9, 542-554. doi: 10.1080/13607860500193336

Wismar, E. C. (2007). Making Institutional Bodies: Socialization into the Nursing Home. Dissertation, University of Waterloo, Waterloo, ON.

Conflict of Interest Statement: The author declares that the research was conducted in the absence of any commercial or financial relationships that could be construed as a potential conflict of interest.

Copyright (c) 2018 Artner. This is an open-access article distributed under the terms of the Creative Commons Attribution License (CC BY). The use, distribution or reproduction in other forums is permitted, provided the original author(s) and the copyright owner(s) are credited and that the original publication in this journal is cited, in accordance with accepted academic practice. No use, distribution or reproduction is permitted which does not comply with these terms. 